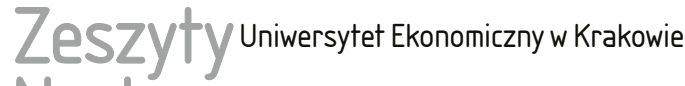 Wuthen
}

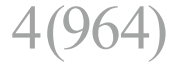

ISSN 1898-6447

Zesz. Nauk. UEK, 2017; $4(964): 135-151$ DOI: $10.15678 /$ ZNUEK.2017.0964.0408

Wojciech Jarecki

\section{Imigracja zarobkowa w Polsce. Stan i perspektywy emigracji z Ukrainy do Polski}

\section{Streszczenie}

Istotnym elementem otoczenia przedsiębiorstwa są zmiany na rynku pracy wywołane imigracją. Zjawisko to dotyczy również przedsiębiorstw w Polsce. Celem artykułu jest odpowiedź na pytania dotyczące wielkości imigracji zarobkowej w Polsce, zawodów wykonywanych przez imigrantów i perspektyw dotyczących wielkości imigracji. Analiza pozwoliła ustalić, że imigracja wynosi ok. 1 mln osób, w większości z Ukrainy. Należy się spodziewać, że w najbliższych latach wielkość migracji z Ukrainy znacząco się nie zmieni.

Słowa kluczowe: migracja, rynek pracy, otoczenie organizacji, kapitał ludzki.

Klasyfikacja JEL: B22, E24, F16, F22.

\section{Wprowadzenie}

W otoczeniu organizacji zachodzą ciągłe zmiany. Jednym z istotnych elementów tego otoczenia jest rynek pracy, na którym dochodzi do zmian zarówno w podaży, jak i w popycie. Dużą dynamikę zmian można w Polsce zaobserwować w zakresie podaży i popytu na pracę, co wynika z ruchów migracyjnych.

Wojciech Jarecki, Uniwersytet Szczeciński, Wydział Nauk Ekonomicznych i Zarządzania, Katedra Zarządzania Kapitałem Ludzkim, ul. A. Mickiewicza 64, 71-101 Szczecin, e-mail: wojciech. jarecki@wneiz.pl 
Do niedawna przedsiębiorcy w naszym kraju odczuwali niedobór pracowników wynikający częściowo z dużej emigracji Polaków. Zmiany polityczno-gospodarcze w Polsce oraz w innych krajach europejskich, a także w krajach azjatyckich wpłynęły na wzrost migracji pracowników do Polski, częściowo redukując pojawiające się niedobory podaży pracy. W związku z tą sytuacją pojawiają się pytania: jak duża jest imigracja zarobkowa w Polsce, $\mathrm{z}$ jakich krajów przybywają imigranci, w jakich zawodach pracują, czy wystąpią istotne zmiany w liczbie imigrantów w Polsce w najbliższych latach oraz jakie są perspektywy związane z imigracją z Ukrainy. Celem artykułu jest odpowiedź na te pytania na podstawie analizy danych statystycznych pochodzących z Ministerstwa Rodziny, Pracy i Polityki Społecznej, GUS, ukraińskiego urzędu statystycznego oraz NBP.

\section{Teoretyczne ujęcie problematyki migracji}

Według Słownika języka polskiego [1992, s. 169] migracje to wszelkie ruchy ludności, mające na celu zmianę miejsca pobytu na stałe lub okresowo. Migracje definiowane są też jako zmiana miejsca zamieszkania, która dokonuje się w przestrzeni geograficznej [Kawczyńska-Butrym 2009, s. 11]. Przestrzeń ta obejmuje wędrówki ludności wewnątrz kraju (migracje wewnętrzne) i na zewnątrz kraju (migracje zewnętrzne, czyli wyjazdy za granicę).

Migracje wewnętrzne wiążą się z przemieszczaniem ludności ze wsi do miast, z mniejszych miejscowości do większych, ale zdarzają się też w odwrotnym kierunku. Główną przyczyną tych migracji jest zwiększenie szans na lepszą pracę, lepszą edukację, poprawę warunków rozwojowych i bezpieczeństwa socjalnego. Miasto daje też większe możliwości dostępu do edukacji, ochrony zdrowia, kultury, uzyskania wyższych dochodów itd.

Migracje zewnętrzne dotyczą przemieszczeń między krajami. Wyróżnia się emigrację i imigrację. Emigracja to wyjazd z kraju rodzinnego do innego kraju, a imigracja oznacza przyjazd do innego kraju [Kawczyńska-Butrym 2009, s. 15].

W ekonomii, ale również w innych naukach, można spotkać wiele teorii dotyczących migracji ludności. Powstawały one ze względu na różne kryteria ich rozpatrywania. Przyjęte kryteria różnią się szczególnie czynnikami determinującymi, którymi kieruje się ludność, decydując się na przekroczenie granicy państwa. Determinantą migracji ekonomicznych jest głównie możliwość polepszenia warunków bytowych. Zgodnie z danymi OECD w migracjach międzynarodowych dominują migracje ekonomiczne.

Warto podkreślić, że wskazywane są różne rodzaje, przyczyny i cele migracji. Można wyróżnić migracje dobrowolne i przymusowe [Lesińska 2010, s. 5]. Pierwsze są dokonywane bez przymusu. Osoba emigrująca czuje dyskomfort 
w związku z warunkami panującymi w państwie i poszukuje lepszych. Migracje przymusowe dokonywane są pod wpływem dodatkowego przymusu zewnętrznego. Jeśli chodzi o cel migracji, najczęstszy jest ekonomiczny. Głównym priorytetem jest chęć znalezienia nowej, lepiej płatnej pracy. Migrantów takich można podzielić na dwie grupy [Kawczyńska-Butrym 2009, s. 18]: 1) migrantów przeżycia, dla których głównym celem jest zdobycie środków potrzebnych do życia (środki na wyżywienie, ubrania, spłacenie długów), 2) migrantów mobilnych, czyli osoby, które mimo zgromadzonych środków szukają możliwości do poprawienia swojego standardu życia (kupno domu, zmiana samochodu, inwestycje).

Można wskazać również czynniki pozaekonomiczne migracji. W zależności od nich migracje dzielimy m.in. na:

- migracje dobrobytu, gdy osoby decydujące się na wyjazd chcą poprawić swój standard życia,

- migracje polityczne, gdy wyjazd następuje pod wpływem sytuacji politycznej,

- migracje patriotyczne, gdy dotyczą powrotu do kraju ojczystego, np. na skutek tęsknoty za nim,

- migracje edukacyjne, dokonywane przez osoby chcące się kształcić, poznawać nowe kultury.

Na migracje ludności mają wpływ czynniki przyciągające i wypychające. Te pierwsze zachęcają do przybycia na dany obszar i mają charakter ekonomiczny (poprawa standardu życiowego dzięki zmianie pracy na lepiej płatną, gwarantującą rozwój osobisty), polityczny (poczucie bezpieczeństwa w państwie, wolność słowa i przekonań) i społeczno-kulturowe (powrót do ojczyzny, do rodziny) [Miłaszewicz i Siedlikowski 2016, s. 110-111]. Czynniki wypychające skłaniają ludność do opuszczenia kraju i również mają charakter ekonomiczny (zła sytuacja gospodarcza, wysokie bezrobocie, ubóstwo, niskie płace), polityczny (konflikty ogólnospołeczne i z innymi państwami, niezadowolenie z rządzących, nieposzanowanie praw człowieka) i społeczno-kulturowy (dyskryminacja ze względów religijnych czy kulturowych, poczucie zagrożenia wynikające z odmienności etnicznej) [Drela 2009, s. 4].

Szerokie i różnorodne badania związane z migracjami, a uwzględniające kwestie etniczne, tożsamościowe, społeczne, w tym problem równowagi płci, statusu społecznego migrantów, zostały przedstawione w monografii pod red. S. Vertovca [2014]. Ujęte są tam również problemy skutków imigracji dla społeczeństwa oraz reakcji rządzących państwami na wzrost imigracji. Z kolei M. Rozkwitalska [2016] zrobiła interesujący przegląd narracyjny publikacji odnoszących się do pracy cudzoziemców, podkreślając w analizie m.in. ich słabszą pozycję na rynku pracy. Natomiast z raportu IMISCOE wynika [Cangiano 2014], że problemem w migracjach jest często status prawny imigrantów, co istotnie wpływa na ich dostęp do rynku pracy w danym kraju. 
Przedstawiona w dużym skrócie problematyka migracji ma swoje przełożenie również na zarządzanie zasobami ludzkimi. Osoby zarządzające pracownikami i całym przedsiębiorstwem są w zasadzie zmuszone do uwzględniania tego zjawiska w planowaniu, rekrutacji, szkoleniach itd. Potrzebna jest do tego wiedza z zakresu teorii migracji dotycząca sytuacji polityczno-gospodarczej w innych krajach oraz sytuacji migrantów na rynku pracy. Ten drugi aspekt zostanie omówiony w kolejnym punkcie.

W kontekście emigracji z Ukrainy do Polski należy wspomnieć o badaniach M. Kindlera i in. [2016]. Analizowali oni dane dotyczące skali i cech współczesnej migracji ukraińskiej w Polsce, głównie rodzaju mobilności krążkowej między sąsiadującymi krajami, która jest zorientowana na pracę i opiera się przede wszystkim na sieciach społecznościowych. Przedstawili też przegląd badań dotyczących tej największej i coraz bardziej zróżnicowanej grupy migrantów. Omówiono cechy społeczno-demograficzne ostatnich ukraińskich imigrantów, ich miejsca pochodzenia i pobytu w Polsce. Dostępna literatura dotycząca migracji ukraińskiej do Polski została również krytycznie przeanalizowana z uwzględnieniem zidentyfikowanych wzorców mobilności. Z kolei S. Przytuła [2014] szeroko przeanalizowała problematykę mobilności i wykonywanej pracy przez ekspatriantów, w tym zajmowanych stanowisk, rozwoju ich kompetencji czy kulturowych uwarunkowań wykonywania pracy. Warto też dodać, że M. Okólski już pod koniec ubiegłego wieku zwracał uwagę, że obywatele Ukrainy emigrują do Polski głównie z przyczyn ekonomicznych [1997, s. 27]. Obecnie pewne znaczenie ma też emigracja edukacyjna z Ukrainy do Polski [Gonda 2017].

\section{Charakterystyka imigrantów w Polsce}

Polska oprócz tego, że jest krajem dużej emigracji, głównie zarobkowej (ponad 2 mln osób czasowo pracujących za granicą), jest też krajem dużej imigracji, szczególnie czasowej (do 6 miesięcy). Warto analizować to zagadnienie, ponieważ pozwoli to przedsiębiorcom przygotować się do zmian na rynku pracy, do planowania potrzeb personalnych, do prognozowania kosztów i efektów działalności czy na wyzwania stojące przed zarządzaniem zasobami ludzkimi w przedsiębiorstwach zatrudniających cudzoziemców [Pocztowski 2015].

Dostępne dane dotyczące imigracji są dwojakiego rodzaju. Jedne, dobrze odzwierciedlające rzeczywistość, dotyczą pozwoleń na pracę, które dostają cudzoziemcy w wojewódzkich urzędach pracy. Drugie dotyczą oświadczeń pracodawców o chęci zatrudnienia cudzoziemca składanych w powiatowych urzędach pracy. Oświadczenia te uprawniają do wykonywania pracy przez okres do 6 miesięcy. Ponadto należy dodać, że trudna do oszacowania liczba osób przyjeżdża do Polski i podejmuje pracę nielegalnie, w ramach odwiedzin itp. 
W tym miejscu przeanalizowane zostaną dane dotyczące zarówno wydawanych pozwoleń na pracę, jak i złożonych oświadczeń. W tym drugim przypadku dane będą interpretowane w uproszczeniu, gdyż przyjęto, że jedno oświadczenie odpowiada jednej zatrudnionej osobie. W pierwszej kolejności zostaną zatem przeanalizowane dane dotyczące pozwoleń na pracę dla cudzoziemców. W tabeli 1 przedstawiono liczbę wydanych pozwoleń na pracę w latach 2008-2016.

Tabela 1. Liczba pozwoleń na pracę dla cudzoziemców w Polsce w latach 2008-2016

\begin{tabular}{|c|c|}
\hline Rok & Liczba wydanych pozwoleń na pracę \\
\hline 2008 & 18022 \\
\hline 2009 & 29340 \\
\hline 2010 & 36622 \\
\hline 2011 & 40808 \\
\hline 2012 & 39144 \\
\hline 2013 & 39078 \\
\hline 2014 & 43663 \\
\hline 2015 & 65786 \\
\hline 2016 & 127394 \\
\hline
\end{tabular}

Źródło: http://www.mpips.gov.pl/analizy-i-raporty/cudzoziemcy-pracujacy-w-polsce-statystyki/, tabela 3 (data dostępu: 16.01.2017).

Na podstawie danych tabeli 1 można stwierdzić, że w kolejnych latach (wyjątkiem był 2013 r.) wzrastała liczba wydawanych pozwoleń na pracę. W 2008 r. uzyskało je 18 tys. osób, w 2009 r. nastąpił wzrost do ponad 29 tys., w kolejnych latach (2011-2014) liczba pozwoleń utrzymywała się na poziomie 40 tys., po czym w 2015 r. nastąpił silny wzrost do prawie 66 tys., a w 2016 r. aż do ponad 127 tys. Największy wzrost liczby pozwoleń można zatem zaobserwować w latach 2015-2016. Z tej właśnie przyczyny dalsza analiza będzie odnosiła się przede wszystkich do lat 2015-2016 i - dla porównania - do lat 2012 i 2014².

W tabeli 2 zaprezentowano dane na temat zezwoleń na pracę według obywatelstwa. Największą liczbę pozwoleń na pracę otrzymali obywatele Ukrainy, przy czym ich udział wzrósł z niespełna 52\% w 2012 r. do ponad 83\% w 2016 r. Jeśli chodzi o inne kraje, w 2016 r. najwięcej pozwoleń otrzymali obywatele Białorusi (prawie 4\%) i Mołdawii (ponad 2\%), ale w latach wcześniejszych udział obywateli

1 Źródłem informacji MRPiPS odnośnie do zatrudnienia cudzoziemców w Polsce są dane na temat wydanych przez wojewodów zezwoleń na pracę (http://psz.praca.gov.pl/rynek-pracy/statystyki-i-analizy/zatrudnianie-cudzoziemcow-w-polsce).

2 Mniejsza liczba analizowanych lat wynika z konieczności ograniczenia objętości artykułu. 
innych krajów był trochę większy. Przykładowo w 2012 r. 8\% stanowili obywatele Chin, a prawie 6\% obywatele Wietnamu; w 2014 r. obywatele tych dwóch krajów mieli w sumie ponad 10-procentowy udział. Od 2015 r. dominują w statystykach obywatele Ukrainy, a udział Białorusinów i Mołdawian to ok. 5-6\%.

Tabela 2. Zezwolenia na pracę dla cudzoziemców według obywatelstwa w latach 2012 i 2014-2016

\begin{tabular}{|l|c|c|c|c|c|c|c|c|}
\hline \multirow{2}{*}{ Wyszczególnienie } & \multicolumn{2}{|c|}{2012} & \multicolumn{2}{c|}{2014} & \multicolumn{2}{c|}{2015} & \multicolumn{2}{c|}{2016} \\
\cline { 2 - 9 } & liczba & $\%$ & liczba & $\%$ & liczba & $\%$ & liczba & $\%$ \\
\hline Ogółem & 39144 & 100,0 & 43663 & 100,0 & 65786 & 100,0 & 127394 & 100,0 \\
\hline Ukraina & 20295 & 51,8 & 26315 & 60,3 & 50465 & 76,7 & 106223 & 83,4 \\
\hline Białoruś & 1949 & 5,0 & 1834 & 4,2 & 2037 & 3,1 & 4870 & 3,8 \\
\hline Mołdawia & 616 & 1,6 & 1027 & 2,4 & 1488 & 2,3 & 2844 & 2,2 \\
\hline Indie & 1090 & 2,8 & 1242 & 2,8 & 1425 & 2,2 & 1762 & 1,4 \\
\hline Chiny & 3269 & 8,4 & 2134 & 4,9 & 1296 & 2,0 & 1215 & 1,0 \\
\hline Nepal & 486 & 1,2 & 402 & 0,9 & 596 & 0,9 & 1211 & 1,0 \\
\hline Rosja & 719 & 1,8 & 654 & 1,5 & 579 & 0,9 & 1008 & 0,8 \\
\hline Uzbekistan & 958 & 2,4 & 1060 & 2,4 & 1433 & 2,2 & 936 & 0,7 \\
\hline Serbia & 188 & 0,5 & 613 & 1,4 & 650 & 1,0 & 904 & 0,7 \\
\hline Turcja & 1063 & 2,7 & 689 & 1,6 & 550 & 0,8 & 672 & 0,5 \\
\hline Wietnam & 2302 & 5,9 & 2369 & 5,4 & 732 & 1,1 & 439 & 0,3 \\
\hline Pozostałe & 7226 & 15,9 & 5829 & 12,2 & 4979 & 6,8 & 5310 & 4,2 \\
\hline
\end{tabular}

Źródło: http://www.mpips.gov.pl/analizy-i-raporty/cudzoziemcy-pracujacy-w-polsce-statystyki/, tabela 2 (data dostępu: 16.01.2017).

Liczba wydanych pozwoleń na pracę wzrasta dynamicznie, ale w całości rynku pracy w Polsce stanowi niespełna $1 \%$. Dlatego też ważniejsza wydaje się analiza danych dotyczących osób mających prawo pracy do 6 miesięcy opartych na oświadczeniach pracodawców (tabela 3).

Liczba oświadczeń o zamiarze powierzenia pracy rosła dosyć dynamicznie, szczególnie od 2014 r. Wyniosła wówczas prawie 390 tys., po czym w 2015 r. było to już ponad 780 tys., a w 2016 r. ponad 1,3 mln. Na tak dużą dynamikę wpływ miały w zasadzie jedynie zmiany w liczbie oświadczeń dla obywateli Ukrainy, którzy mają prawie 100-procentowy udział we wszystkich oświadczeniach. Warto jednak zwrócić również uwagę na czterokrotny wzrost liczby oświadczeń dla obywateli Białorusi (2016 r. w stosunku do 2015 r.).

Przedstawione wcześniej dane uzupełniono o analizę wieku osób, na które wystawiono oświadczenia, wybranych sekcji PKD i grup zawodów (tabele 4 i 5). 


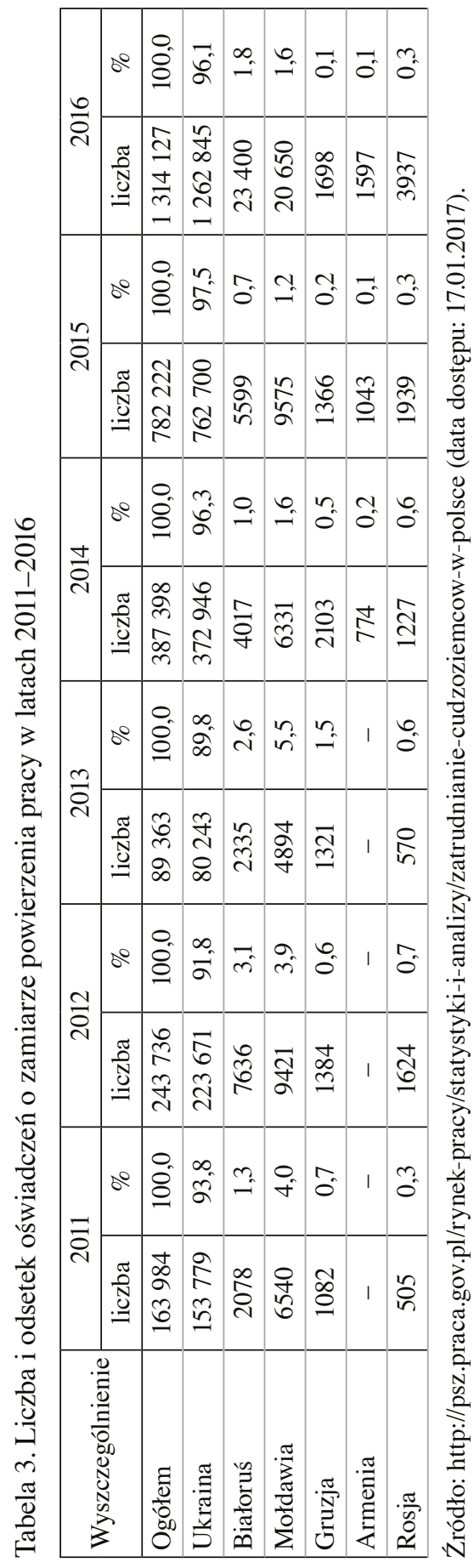


Tabela 4. Liczba oświadczeń zarejestrowanych przez powiatowe urzędy pracy* oraz struktura wiekowa pracowników w latach 2012 i 2014-2016

\begin{tabular}{|l|c|c|c|c|}
\hline \multicolumn{1}{|c|}{ Wyszczególnienie } & 2012 & 2014 & 2015 & 2016 \\
\hline Liczba oświadczeń & 243736 & 387398 & 782222 & 1314127 \\
\hline Struktura wiekowa pracowników (w \%) & & & & \\
\hline poniżej 26 lat & 24,4 & 26,4 & 26,4 & 25,5 \\
\hline 26-40 lat & 43,9 & 43,4 & 45,3 & 45,3 \\
\hline 41-65 lat & 31,5 & 30,0 & 28,2 & 29,1 \\
\hline powyżej 65 lat & 0,2 & 0,2 & 0,1 & 0,1 \\
\hline
\end{tabular}

* Rejestracja oświadczeń pracodawców o zamiarze powierzenia pracy cudzoziemcowi dotyczy cudzoziemców podejmujących krótkoterminowe zatrudnienie w Polsce, o których mowa w $§ 1$ pkt 22 Rozporządzenia Ministra Pracy i Polityki Społecznej z 20 lipca 2011 r. w sprawie przypadków, w których powierzenie wykonywania pracy cudzoziemcowi na terytorium Rzeczypospolitej Polskiej jest dopuszczalne bez konieczności uzyskania zezwolenia na pracę (Dz.U. nr 155 poz. 919). Należy pamiętać, że liczba cudzoziemców, którzy podjęli pracę w związku z zarejestrowanym oświadczeniem nie musi być tożsama z liczbą zarejestrowanych oświadczeń. Wynika to m.in. z faktu, że dla części cudzoziemców zarejestrowano więcej niż jedno oświadczenie, a także z odmowy udzielenia wizy niektórym cudzoziemcom czy też rezygnacji niektórych z nich z przyjazdu do Polski.

Źródło: http://www.mpips.gov.pl/analizy-i-raporty/cudzoziemcy-pracujacy-w-polsce-statystyki/ (data dostępu: 17.01.2017).

W latach 2012-2016 nastąpiły pewne zmiany w strukturze wiekowej imigrantów (tabela 4). Analizując dane z lat 2015-2016, można zaobserwować wzrost odsetka osób w wieku 26-40 lat i zmniejszenie się odsetka osób po 40 roku życia w stosunku do 2012 i 2014 r.

W tabeli 5 przedstawiono dane dotyczące oświadczeń według sekcji PKD i grup zawodów. Najwięcej osób przyjeżdżających do Polski pracować przez okres do 6 miesięcy podejmuje pracę ${ }^{3} \mathrm{w}$ sekcjach: działalność w zakresie usług administrowania i działalność wspierająca; rolnictwo, leśnictwo, łowiectwo i rybactwo; budownictwo (tabela 5). W analizowanym okresie następowały jednak istotne zmiany: wzrastał dynamicznie odsetek oświadczeń dla osób podejmujących pracę w pierwszej z tych sekcji (z ok. 9\% w 2014 r. do prawie 29\% w 2016 r.), a w rolnictwie zmniejszył się z prawie 47\% w 2012 r. do niecałych $26 \%$ w 2016 r. Zmniejszył się też w latach 2012-2016 udział pracujących w budownictwie z 22\% do niecałych $13 \%$.

Jeśli chodzi o grupy zawodów, zdecydowanie najwięcej osób było zatrudnionych jako pracownicy przy pracach prostych (ok. 60\% w latach 2014-2016), a następnie jako robotnicy przemysłowi i rzemieślnicy (wzrost z niespełna 13\% w 2014 r. do prawie 19\% w 2016 r.). Warto zauważyć, że najniższy jest, a ponadto

${ }^{3}$ Zakładając, że rodzaj pracy odpowiada złożonemu przez pracodawcę oświadczeniu. 
zmniejsza się odsetek osób zatrudnionych na stanowiskach wymagających wysokich kwalifikacji, czyli pracujących jako przedstawiciele władz publicznych, wyżsi urzędnicy i kierownicy oraz specjaliści.

Tabela 5. Liczba i struktura oświadczeń zarejestrowanych przez powiatowe urzędy pracy w latach 2012 i 2014-2016 według sekcji PKD i grup zawodów

\begin{tabular}{|l|c|c|c|c|}
\hline \multicolumn{1}{|c|}{ Wyszczególnienie } & 2012 & 2014 & 2015 & 2016 \\
\hline Liczba oświadczeń & 243736 & 387398 & 782222 & 1314127 \\
\hline Struktura oświadczeń według sekcji PKD (w \%) & & & & \\
\hline rolnictwo, leśnictwo, łowiectwo i rybactwo & 46,6 & 46,0 & 35,4 & 25,6 \\
\hline przetwórstwo przemysłowe & 6,7 & 11,4 & 13,8 & 12,7 \\
\hline budownictwo & 22,1 & 14,1 & 14,2 & 12,8 \\
\hline $\begin{array}{l}\text { handel hurtowy i detaliczny, naprawa pojazdów } \\
\text { samochodowych, motocykli }\end{array}$ & 2,7 & 4,2 & 4,5 & 3,9 \\
\hline transport i gospodarka magazynowa & 3,0 & 3,2 & 3,8 & 4,8 \\
\hline $\begin{array}{l}\text { działalność w zakresie usług administrowania } \\
\text { i działalność wspierająca }\end{array}$ & - & 8,5 & 16,0 & 28,8 \\
\hline pozostała działalność usługowa & - & 4,4 & 5,0 & 3,4 \\
\hline pozostałe & 18,9 & 8,2 & 7,3 & 8,8 \\
\hline Struktura oświadczeń według grup zawodów (w \%) & & & & \\
\hline $\begin{array}{l}\text { przedstawiciele władz publicznych, wyżsi urzędnicy } \\
\text { i kierownicy }\end{array}$ & - & 0,1 & 0,2 & 0,1 \\
\hline specjaliści & - & 1,6 & 1,4 & 0,7 \\
\hline technicy i inny średni personel & - & 0,9 & 1,4 & 2,0 \\
\hline pracownicy biurowi & - & 1,7 & 2,6 & 3,6 \\
\hline pracownicy usług i sprzedawcy & - & 9,5 & 7,2 & 4,9 \\
\hline $\begin{array}{l}\text { rolnicy, ogrodnicy, leśnicy i rybacy } \\
\text { robotnicy przemysłowi i rzemieślnicy }\end{array}$ & - & 12,9 & 17,3 & 18,9 \\
\hline operatorzy i monterzy maszyn i urządzeń & - & 3,0 & 5,9 & 8,5 \\
\hline pracownicy przy pracach prostych & - & 58,2 & 57,1 \\
\hline
\end{tabular}

Źródło: http://www.mpips.gov.pl/analizy-i-raporty/cudzoziemcy-pracujacy-w-polsce-statystyki/ (data dostępu: 17.01.2017).

W ramach uzupełnienia warto dodać, że liczba cudzoziemców zarejestrowanych w Polsce jako bezrobotni wyniosła na koniec grudnia 2015 r. prawie 3,8 tys., co stanowiło zaledwie ok. 0,24\% ogółu zarejestrowanych bezrobotnych. Na koniec grudnia 2015 r. 238 cudzoziemców posiadało prawo do zasiłku, co stanowiło ok. 6\% wszystkich cudzoziemców zarejestrowanych jako osoby bezrobotne [Informacja nt. zatrudniania... 2016]. 
Ponieważ ponad $90 \%$ pracujących imigrantów w Polsce to obywatele Ukrainy, dalsza analiza będzie dotyczyła perspektyw napływu na rynek pracy imigrantów $\mathrm{z}$ tego kraju.

\section{Sytuacja polityczno-gospodarczo-społeczna na Ukrainie}

Dane wskazujące, że imigranci w Polsce pochodzą głównie z Ukrainy mogą sugerować, że emigracja z tego kraju wywołana jest bezpośrednio konfliktem zbrojnym Rosji i Ukrainy. Teza ta jest bardzo prawdopodobna w przypadku emigracji ze wschodniej Ukrainy do Rosji ${ }^{4}$. Do Rosji wyjeżdżają osoby mające pochodzenie rosyjskie lub Rosjanie mieszkający na Ukrainie. Jeśli chodzi o przyczyny emigracji do Polski sytuacja jest nieco inna, choć w dużej części, szczególnie w odniesieniu do emigracji po 2014 r., ma ona związek z konfliktem ukraińsko-rosyjskim. Konflikt ten wpływa na pogorszenie sytuacji gospodarczej Ukrainy, w tym na likwidację miejsc pracy szczególnie w przedsiębiorstwach związanych z górnictwem i przemysłem ciężkim we wschodniej jej części, w której sukcesywnie likwidowane są kopalnie ${ }^{5}$ zakłady przemysłowe. Przyznać jednak należy, że od 2015 r. zwiększa się również emigracja z wschodniej Ukrainy do Polski.

Kryzysowa sytuacja gospodarcza Ukrainy dotyczyła w szczególności 2014 r., gdy miały miejsce największe działania zbrojne. Zanotowano wówczas duży spadek gospodarczy, wzrost inflacji i znaczny spadek dochodów realnych ludności. Na przełomie lat 2016 i 2017 sytuacja gospodarcza była niewiele lepsza. Co prawda PKB wzrósł o 0,5\% (rok do roku), ale zmniejszyła się siła nabywcza, bezrobocie wyniosło ponad 9\% (przy czym wydaje się zaniżone, gdyż przedsiębiorstwa państwowe ograniczają zwolnienia ze względów społecznych), inflacja wyniosła ponad 12\%, dramatycznie wzrósł dług publiczny (http://www.tradingeconomics.com/ukraine/indicators, data dostępu: 15.05.2017).

Konflikt zbrojny i związana z nim zapaść gospodarcza wpływają na skłonność do emigracji, ale też nie są jedynymi czynnikami emigracji z Ukrainy. Problem jest szerszy, bardziej złożony. Ciężkie warunki pracy w przedsiębiorstwach (zwłaszcza w przemyśle wydobywczym i metalurgicznym), degradacja środowiska naturalnego, niezdrowy tryb życia mieszkańców (szczególnie alkoholizm), a także wiele innych subiektywnych i obiektywnych czynników społeczno-kulturowych powo-

${ }^{4}$ Na Ukrainie wyróżnia się trzy główne regiony: wschodni, centralny i zachodni.

5 Do wybuchu wojny na wschodzie Ukrainy działały 135 kopalnie. Teraz państwu podlega 35 kopalń, ale działa nie więcej niż 20 (http://nettg.pl/news/128065/ukraina-gornictwo-weglowe-w-ruinie, data dostępu: 20.04.2017). 
dują, że ludzie żyją stosunkowo krótko ${ }^{6}$, chorują, niski jest wskaźnik dzietności [Sokołowski 2015, s. 49]. Trochę korzystniejsze dane demograficzne dotyczące zachodniej Ukrainy tłumaczone są znacznie niższym poziomem industrializacji, dużym odsetkiem ludności wiejskiej i przywiązaniem do tradycyjnych wartości. Wspomniane negatywne czynniki społeczno-gospodarczo-demograficzne występują od dawna, a ich wyrazem jest chociażby zmniejszenie się liczby ludności Ukrainy z 52 mln w 1991 r. do 43 mln w 2016 r. [Nasieliennaja Ukraini... 2017].

Warto uzupełnić powyższe informacje o dane na temat zmian ludności w określonych grupach wiekowych. Dane z lat 1990-2016 dotyczące osób w wieku produkcyjnym (16-59 lat) pokazują negatywne tendencje. Liczba ludności w wieku produkcyjnym spadła z 30291 tys. w 1990 r. do 28372 tys. w 2014 r. i do 26317 tys. w 2016 r. (www.ukrstat.gov.ua, data dostępu: 10.04.2017). Dane dotyczące 5-letnich grup wiekowych przedstawiono w tabeli 6.

Tabela 6. Ludność Ukrainy według grup wiekowych (stan na 31 grudnia 2015 r.)

\begin{tabular}{|c|c|}
\hline Grupa wiekowa & Liczba ludności (w tys.) \\
\hline 0-4 lat & 2301 \\
\hline 5-9 lat & 2295 \\
\hline 10-14 lat & 1898 \\
\hline 15-19 lat & 1974 \\
\hline 20-24 lat & 2590 \\
\hline 25-29 lat & 3375 \\
\hline 30-34 lat & 3539 \\
\hline 35-39 lat & 3177 \\
\hline $40-44$ lat & 3040 \\
\hline $45-49$ lat & 2816 \\
\hline 50-54 lat & 3037 \\
\hline $55-59$ lat & 3130 \\
\hline $60-64$ lat & 2648 \\
\hline 65 lat i więcej & 6768 \\
\hline
\end{tabular}

Źródło: [Nasieliennaja Ukraini... 2017, s. 18-20].

Z danych zaprezentowanych w tabeli 6 wynika, że najwięcej osób ma 30-34 lat (3539 tys.) oraz 25-29 lat (3375 tys.). Można zaobserwować duży spadek liczby ludności w młodszych grupach wiekowych, tj. mających 20-24 lat (2590 tys.) oraz

${ }^{6}$ Długość życia kobiet w Ukrainie wynosi 72-73 lata, natomiast mężczyzn 60-65 lat [Nasieliennaja Ukraini... 2017, s. 114-118], czyli zarówno kobiety, jak i mężczyźni żyją ok. 10 lat krócej niż w Polsce. 
15-19 lat (1974 tys.). Spadek ten ma istotne znaczenie dla prognoz dotyczących imigracji do Polski, o czym będzie mowa w dalszej części artykułu.

W kontekście oceny perspektyw wielkości imigracji z Ukrainy ważne są dane dotyczące powodów przyjazdu do Polski (tabela 7).

Tabela 7. Główne powody przyjazdu do Polski migrantów z Ukrainy

\begin{tabular}{|l|c|c|}
\hline \multicolumn{1}{|c|}{ Powody } & $\begin{array}{c}\text { Imigranci przybywający } \\
\text { do Polski do 2013 r. (w \%) }\end{array}$ & $\begin{array}{c}\text { Imigranci przybywający } \\
\text { do Polski od 2014 r. (w \%) }\end{array}$ \\
\hline Niezadowalający poziom wynagrodzenia & 49,7 & 59,8 \\
\hline Brak pracy & 36,1 & 20,1 \\
\hline Sytuacja polityczna & 3,5 & 12,5 \\
\hline Inne & 10,8 & 7,6 \\
\hline
\end{tabular}

Źródło: [Chmielewska, Dobroczek i Puzynkiewicz 2016, s. 12].

Głównym powodem przyjazdów do Polski był niezadowalający poziom wynagrodzenia, ale wśród imigrantów przybywających do naszego kraju od 2014 r. jest on ważniejszy o 10 pkt proc. (prawie 60\%) niż wśród imigrantów przybywających wcześniej. Drugim co do ważności powodem był brak pracy, ale był on znacznie ważniejszy dla imigrantów sprzed 2014 r. (o 16 pkt proc.). Wśród młodszej imigracji większego znaczenia nabrała sytuacja polityczna.

W tabeli 8 przeanalizowano sytuację rodzinną imigrantów. Jest to istotne szczególnie w odniesieniu do prognozowania trwałości imigracji, czyli odpowiedzi na pytanie, czy imigrant ma silny czynnik przyciągający do powrotu.

Największe różnice można zaobserwować w sytuacji rodzinnej imigrantów. Do 2013 r. przyjeżdżały głównie osoby będące w związkach małżeńskich/partnerskich (prawie 55\%) i mające dwoje dzieci i więcej (ponad 54\%). Od 2014 r. przyjeżdżają głównie imigranci stanu wolnego (prawie 46\%) i niemający dzieci (54\%).

Tabela 8. Sytuacja rodzinna migrantów - stan cywilny i liczba posiadanych dzieci

\begin{tabular}{|l|c|c|}
\hline \multicolumn{1}{|c|}{ Wyszczególnienie } & $\begin{array}{c}\text { Imigranci przybywający } \\
\text { do Polski do 2013 r. (w \%) }\end{array}$ & $\begin{array}{c}\text { Imigranci przybywający } \\
\text { do Polski od 2014 r. (w \%) }\end{array}$ \\
\hline Stan cywilny & 21,1 & 45,6 \\
\hline kawaler/panna & 54,8 & 42,2 \\
\hline związek małżeński/partnerski & 24,1 & 12,2 \\
\hline inny & & 23,4 \\
\hline Liczba dzieci & 54,4 & 22,6 \\
\hline dwoje dzieci i więcej & 21,2 & 54,0 \\
\hline jedno dziecko & 24,4 & \\
\hline brak dzieci & & \\
\hline
\end{tabular}

Źródło: [Chmielewska, Dobroczek i Puzynkiewicz 2016, s. 14]. 
Powyższe dane warto uzupełnić następującymi informacjami:

- w zdecydowanej większości Ukraińcy przyjeżdżający do pracy w Polsce to osoby dobrze wykształcone. Z osób badanych w 2014 r. 37,7\% miało wykształcenie wyższe ${ }^{7}$, a 53,9\% średnie (ogólnokształcące lub zawodowe). Jedynie 8,4\% miało wykształcenie zawodowe lub niższe;

- średnie wynagrodzenie migrantów było zbliżone do mediany zarobków w polskiej gospodarce, która według danych GUS wynosiła w 2014 r. 3292 zł brutto (ok. 2300 zł netto). Wyniki wskazują jednak, że aby osiągnąć taki dochód, musieli pracować 54 godz. tygodniowo;

- 31 tys. studentów ${ }^{8}$ w roku akademickim 2015/2016 pochodziło z Ukrainy [Szkoły wyższe... 2016, s. 35], z tego ok. połowa pracowała ponad 30 godzin tygodniowo, kolejne $25 \%$ chciało podjąć pracę, a 1/3 chciała zostać w Polsce na dłużej.

\section{Perspektywy emigracji z Ukrainy do Polski}

Analiza sytuacji wewnętrznej Ukrainy, szczególnie konfliktu ukraińsko-rosyjskiego, wskazuje, że nie nastąpią istotne zmiany tendencji emigracyjnych z Ukrainy w najbliższych kilku latach, nawet mimo wprowadzenia ułatwień w podejmowaniu pracy w okresie do 3 miesięcy w lepiej rozwiniętych krajach UE. Ukrainie grozi dalsza emigracja ludności w wieku produkcyjnym. 65\% Ukraińców w wieku 14-35 lat chce wyjechać za granicę na stałe lub tymczasowo. Według ukraińskich danych w 2015 r. za granicą pracowało 3-5 mln Ukraińców [Trojan 2016], przy czym wielkość tej emigracji w krajach innych niż Polska jest względnie stała. Polska jest jedynym krajem w Unii Europejskiej, w którym od początku 2015 r. widać duży wzrost migracji z Ukrainy. Na wzrost emigracji do Polski wpływ ma kilka czynników. Przede wszystkim jest to pokrewieństwo językowe, stosunkowo bliska odległość, szczególnie jeśli chodzi o zachodnią Ukrainę, poprawiająca się kondycja polskiej gospodarki i związany z tym popyt na pracowników wykonujących prace niskopłatne, uproszczenia w dostępie do rynku pracy przyznane obywatelom krajów Partnerstwa Wschodniego, szczególnie w postaci tzw. oświadczeń o zatrudnieniu, dzięki któremu obywatel Ukrainy chcący pracować czasowo w Polsce jest zwolniony z konieczności uzyskiwania zezwolenia na pracę (wystarczy, że będzie posiadał oświadczenie o zamiarze powierzenia pracy zarejestrowane w powiatowym urzędzie pracy [Jaroszewicz 2015] ${ }^{9}$.

7 W 2012 r. 40\% imigrantów z Ukrainy miało wyższe wykształcenie [A New Profile... 2014, s. 5].

${ }^{8}$ Ok. 50\% cudzoziemców studiujących w Polsce.

9 Należy nadmienić, że oświadczenia o zatrudnieniu dotyczą prac krótkoterminowych, trwających do 6 miesięcy. 
Jeśli chodzi o prognozy, ważną informacją jest to, że coraz więcej Ukraińców rozważa emigrację. Według sondażu GfK Ukraina 8\% Ukraińców, czyli ok. 3 mln osób, planuje w najbliższej przyszłości wyjechać do pracy za granicę ${ }^{10}$. Ankietowani jako kraj docelowy najczęściej wskazywali Polskę (30\%). W podobnych badaniach przeprowadzonych w 2006 r. było to jedynie 7\% [Ukraincy nie udajq... 2015]. W perspektywie wieloletniej warto jednak uwzględnić fakt, że wśród osób wieku 10-19 lat na Ukrainie jest duży niż demograficzny i w związku z tym, przy utrzymującym się odsetku osób chcących emigrować może nastąpić spadek liczby osób emigrujących z powodu niżu demograficznego.

Obecne tendencje wskazują, że wychodzenie z kryzysu gospodarczego będzie na Ukrainie długotrwałe, chociażby z powodu dużego spadku produkcji, sztucznie utrzymywanego, zaniżonego poziomu bezrobocia czy przedłużającego się konfliktu z Rosją. Warto też zauważyć, że wśród nowych imigrantów mniej jest osób posiadających dzieci i małżonków, dlatego część z tych osób może nie mieć motywacji, by wrócić na Ukrainę, i będzie chciała pozostać w Polsce na stałe.

\section{Wnioski}

Imigrację zarobkową w Polsce w 2016 r. można szacować na przynajmniej 1 mln osób. Zdecydowaną większość stanowią obywatele Ukrainy, przy czym w 2016 r. wzrosła znacznie liczba imigrantów z Białorusi. Dokładną liczbę wszystkich imigrantów w Polsce trudno ustalić ze względu na podejmowanie pracy na podstawie oświadczeń, a także fakt, że część osób pracuje nielegalnie.

Imigranci, mimo że dobrze wykształceni, najczęściej wykonują prace proste w sekcjach: działalność w zakresie usług administrowania i działalność wspierająca, rolnictwo, leśnictwo, łowiectwo i rybactwo oraz budownictwo. Z punktu widzenia efektywności wykonywanie głównie prac prostych przez osoby stosunkowo dobrze wykształcone przekładać się może na wysoce wydajną pracę przy stosunkowo niskich kosztach ${ }^{11}$. Przy pracach prostych, dla części Polaków, są być może konkurencją, ale bez wątpienia pełnią funkcję uzupełniającą podaż pracy, wpływając na obniżenie kosztów funkcjonowania przedsiębiorstw. Stosunkowo

${ }^{10}$ Sprzyjać temu będą też wprowadzane przez Wizzair i Ryanair połączenia lotnicze między Kijowem i Lwowem a miastami w Polsce, Wielkiej Brytanii i Niemczech czy nowe połączenie kolejowe Kijów-Rzeszów [Dokq̨d będzie latać... 2017].

${ }^{11}$ Dyrektor jednego z przedsiębiorstw w województwie zachodniopomorskim powiedział, że zatrudnienie ,przy produkcji” imigranta z Ukrainy przez firmę pośrednictwa pracy kosztuje go 2500 zł miesięcznie, podczas gdy koszt zatrudnienia Polaka wynosi ok. 5000-6000 zł przy dużej fluktuacji. 
dobre wykształcenie imigrantów być może będzie się w przyszłości przekładało na zajmowanie przez nich wyższych stanowisk w przedsiębiorstwach.

Na podstawie informacji zawartych w tabelach 7 i 8 można wyciągnąć dodatkowe wnioski, że czynnikami wypychającymi z Ukrainy i przyciągającymi do Polski są: wysokość wynagrodzeń, inflacja i stopa bezrobocia. Poza tym czynnikiem nieprzyciągającym do Ukrainy jest niższy odsetek osób, które zostawiają na Ukrainie małżonków i dzieci.

Przedstawiona analiza wskazuje, że Polska, również dzięki ułatwieniom administracyjnym dla imigrantów z Ukrainy, łatwości komunikacji językowej i przestrzennej, przyzwyczajeń do wykonywania określonych prac i do pracodawców, umacnia swoją pozycję kraju docelowej imigracji zarobkowej dla mieszkańców Ukrainy. Istnieje duże prawdopodobieństwo, że jeszcze przez kilka lat poziom tej imigracji będzie się utrzymywał, a nawet wzrastał w najbliższych 2-3 latach, następnie zaś będzie się powoli obniżał z powodów demograficznych, a być może również z przyczyny dalszej migracji do krajów zamożniejszych, oferujących wyższe płace. Dalsza emigracja nie powinna być jednak duża ze względu na emigrację z krajów azjatyckich do Europy Zachodniej i wzrastającą popularność organizacji antyimigracyjnych, szczególnie w Niemczech i we Włoszech, do których częściej emigrowali Ukraińcy. Nie wiadomo również, jaki kierunek będzie miała, na razie restrykcyjna, polityka migracyjna krajów Grupy Wyszehradzkiej, w której stopa bezrobocia jest bardzo niska (Węgry i Czechy), a które wolą migrantów z Ukrainy niż z Azji. Być może część migrantów z Ukrainy podąży do tych krajów.

\section{Literatura}

Cangiano A. [2017], Migration Policies and Migrant Employment Outcomes Conceptual Analysis and Comparative Evidence for Europe, IMISCOE, Amsterdam University Press, Amsterdam.

Chmielewska I., Dobroczek G., Puzynkiewicz J. [2016], Obywatele Ukrainy pracujqcy w Polsce - raport z badania, NBP, Warszawa.

Dokqd będzie latać z Ukrainy Ryanair [2017], http://wschodnik.pl/ukraina/item/10614-dokad-bedzie-latac-z-ukrainy-ryanair.html (data dostępu: 15.02.2017).

Drela K. [2009], Emigracja w XXI wieku - migracje pracowników [w:] Zarzqdzanie kapitałem ludzkim w gospodarce opartej na wiedzy, red. E. Skrzypek, A. Sokół, Instytut Wiedzy i Innowacji, Warszawa.

Gonda M. [2017], Mobilność edukacyjna w sytuacji migracji do korzeni: przypadek młodej polskiej diaspory ze Wschodu, „Studia Migracyjne - Przegląd Polonijny”, z. 1/163.

Informacja nt. zatrudniania cudzoziemców w Polsce [2016], http://www.mpips.gov.pl/gfx/ mpips/userfiles/_public/1_NOWASTRONA/Analizyiraporty/cudzoziemncypracujacywpolsce/zatrudnianiecudzoziemcow2016.pdf (data dostępu: 30.03.2017).

Janicki W. [2007], Przeglqd teorii migracji ludności, Wydawnictwo UMCS, Lublin. 
Jaroszewicz M. [2015], Kryzysowa migracja Ukrainców, https://www.osw.waw.pl/pl/ publikacje/komentarze-osw/2015-10-19/kryzysowa-migracja-ukraincow (data dostępu: 25.01.2017).

Kawczyńska-Butrym Z. [2009], Migracje. Wybrane zagadnienia, UMCS, Lublin.

Kindler M., Brunarska Z., Szulecka M., Toruńczyk-Ruiz S. [2017], Ukrainian Migration to Poland: A "Local" Mobility? [w:] Ukrainian Migration to the European Union. Lessons from Migration Studies, red. O. Fedyuk, M. Kindler, Springer, Amsterdam.

Lesińska M. [2010], Polityka państwa wobec migracji powrotnych własnych obywateli. Teoria i praktyka, Ośrodek Badań nad Migracjami, Warszawa.

Miłaszewicz D., Siedlikowski C. [2016], Zmiany demograficzne i procesy migracyjne oraz ich oddziaływanie na rynku pracy, ,Studia Ekonomiczne. Zeszyty Naukowe Uniwersytetu Ekonomicznego w Katowicach", nr 276.

Nasieliennaja Ukraini za 2015 [2017], http://database.ukrcensus.gov.ua/PXWEB2007/ukr/ publ_new1/2016/naselen_2015.pdf (data dostępu: 27.01.2017).

A New Profile of Migrants in the Aftermath of the Recent Economic Crisis [2014], OECD, http://www.oecd.org/els/mig/WP160.pdf (data dostępu: 30.08.2016).

Okólski M. [1997], Najnowszy ruch wędrówkowy z Ukrainy do Polski. Charakterystyka strumieni, cech migrantów i okoliczności pobytu w Polsce, CMR Working Papers, nr 14.

Pocztowski A. [2015], Geneza, rozwój i zakres międzynarodowego zarzq̨dzania zasobami ludzkimi [w:] Zarzqdzanie zasobami ludzkimi na rynkach międzynarodowych, red. A. Pocztowski, Wolters Kluwer Polska, Warszawa.

Przytuła S. [2014], Zarzq̨dzanie kadrq ekspatriantów w filiach przedsiębiorstw międzynarodowych w Polsce, Wydawnictwo CeDeWu, Warszawa.

Rozkwitalska M. [2016], Efekt kraju pochodzenia a ocena kompetencji zawodowych obcokrajowca - przegląd narracyjny, „Przedsiębiorczość i Zarządzanie”, t. XVII, z. 2(3).

Sokołowski W. [2015], Demograficzny potencjał Ukrainy i jego przyszłość, http://www. forum-ekonomiczne.pl/article/demograficzny-potencjal-ukrainy-i-jego-przyszlosc/\#. WIW3Kk0iyUl (data dostępu: 14.04.2015).

Słownik jęzka polskiego [1992], red. M. Szymczak, t. 2, PWN, Warszawa.

Szkoły wyższe i ich finanse w 2015 roku [2016], GUS, Warszawa.

Trojan M. [2016], Fala młodych Ukraińców chce ruszyć na Zachód, http://www.kresy. $\mathrm{pl}$ /wydarzenia,spoleczenstwo?zobacz/ukraincy-masowo-opuszczaja-swoj-kraj (data dostępu: 20.05.2017).

Ukraincy nie udajq. 3 mln Ukraińców chce emigrować za pracq. Najchętniej-do Polski [2015], https://wirtualnapolonia.com/2015/08/03/ukraincy-nie-udaja-3-mlnukraincow-chce-emigrowac-za-praca-najchetniej-do-polski/ (data dostępu: 8.03.2015).

Vertovec S. [2014], Migration and Diversity, International Library of Studies on Migration Series, Max Planck Institute for the Study of Religious and Ethnic Diversity, Getynga.

\section{Labour Immigration to Poland - the Present Situation and the Future of Labour Emigration from Ukraine to Poland}

(Abstract)

Changes on the labour market due to immigration are an important element of the business environment. This phenomenon affects companies in Poland as well. The present paper provides an answer to several questions concerning the amount of labour immigration 
to Poland, the professions immigrants engage in and the predicted amount of labour immigration. The analysis revealed that the number of immigrants, mostly from Ukraine, oscillates around 1 million and that the majority of them perform simple jobs. It is to be expected that in the near term, migration from Ukraine will not change considerably.

Keywords: migration, labour market, organisational environment, human capital. 